\title{
Geo-information Science for Sustainable Development of Mount Stong F.R., Kelantan, Malaysia
}

\author{
Kamaruzaman Jusoff (Corresponding author) \\ School of Forestry \& Environmental Studies \\ Yale University \\ 205 Prospect St, New Haven, CT 06511, USA \\ Tel: 20-3-432-1384Ｅ-mail: jusoff.kamaruzaman@yale.edu
}

\author{
A.K Skidmore \\ Department of Natural Resources \\ International Institute for Geoinformation Science \& Erath Observation \\ ITC, Helongstraat 99, P.O.Box 6, 7500 AA Enschede, The Netherlands \\ Tel: 31-53-487-4276 E-mail: skidmore@itc.nl
}

\begin{abstract}
The state of Kelantan covers an area of 1.5 million hectares of which about 894,271 hectares or $60 \%$ is under forest cover. It is still very much endowed with a rich and diverse biodiversity, such as in the dipterocarp forests of the reserves, in the National Park, limestone hills of Gua Musang, mountain forests of the Main Range, and Virgin Jungle Reserves. It is fortunate in that it has vast areas of lowlands, high rolling mountains and hills, with a rich and unique biodiversity associated with those ecosystems. A scientific expedition to the Mount Stong Tengah Forest Reserve in 2003 discovered that the area has a unique and diverse ecosystem, rich in bio-diversity and many endemic species. These findings prompted the State of Kelantan to gazette the entire central Mt. Stong Permanent Forest Reserve, one of its prime production forests, totaling 21,950 hectares, into a state forest park. Consequently, the State Forestry Department of Kelantan planned to turn these mountain forest resources into the best managed and successful state forest park and to achieve this, an integrated and multi functional approach has to be adopted. Initially, a thorough study of the mountain forest park resources involving Universiti Putra Malaysia-Aeroscan Precision (M) Sdn Bhd's airborne hyperspectral imaging technology system has been undertaken. Preliminary results indicated that airborne hyperspectral sensing can easily identify individual timber species, estimate their timber volume, locate and map cultural, historical, mountain peaks, caves, waterfalls, picnic and camping sites potential and suitable for forest eco-tourism and recreational activities in Mt. Stong to be developed as a state forest park. Once completed, a 100 Year Management Plan will be formulated to assist the state government to undertake the best strategies towards implementing programs such as forest eco-tourism, publicity, local or international events, research facilities, and infrastructure, appropriate for a best managed and successful mountain state forest park.
\end{abstract}

Keywords: Airborne, Hyperspectral sensing, Sustainable development, Mountain forest, State Forest park

\section{Introduction}

Effective management of tropical mountain forest resources which are complex, especially in Mt. Stong, Kelantan requires accurate and up-to-date information to guide the data collection, such as cloud cover. To help the State Forest Park Manager make critical management decisions on the recently gazetted entire central Mt. Stong State Forest Park $(21,950 \mathrm{ha})$, they need geo-spatial data in the forms of map and real-time digital data in an integrated system where it can be easily and quickly gathered, organized, analyzed and mapped to find patterns and relationships that were previously unrecognized. This in turn gives them a deeper understanding of the issues they face, and lets them bring more information and less conjecture to the problem solving process. The airborne hyperspectral sensing/GIS fills this gap by providing spatial analysis tools to support decision making. The objective of this paper is therefore to demonstrate the capabilities of a UPM-APSB's AISA airborne hyperspectral imaging sensor in developing management principles of developing Mt. Stong mountain forest as a State Forest Park The proposed Management Plan establishes broad principles for the development, management and planning of the Mt Stong as a State Forest Park and provides a series of best management practices (BMP) and actions based from an airborne spectral imaging technology. The primary aim of this 
BMP is to ensure that the mountain forest resources of Mt. Stong is managed as a State Forest Park in an environmentally sensitive, sustainable and economically viable manner. It also seeks to ensure that managing Mt. Stong is a continuous process, responsive to changing local people expectations and expanding knowledge of the forest ecosystem.

\section{Current status of forest resources in the state of Kelantan}

Kelantan is the northern-most state on the East Coast of Peninsular Malaysia. It has an area of 1493,181 ha or 14,931 km² of which about 894,271 ha or $60 \%$ is under forest cover (Dahlan and Abdullah, 2006). The state is steeped in tradition and culture with vast stretches of tropical forests. The total forest area in Kelantan state Forest Management Unit (FMU) amounts to 894271 ha. Of this total, 629687 ha were gazetted as Permanent Forest Estate (PFE), 108,783 as National Park/Wildlife Reserves, and the remaining 155,801 ha categorized as Stateland Forest (Table 1).

It is still very much endowed with a rich and diverse biodiversity, such as in the dipterocarp forests of the reserves, in the National Park, limestone hills of Gua Musang, montane forests of the Main Range, Virgin Jungle Reserves etc. It is fortunate in that it has vast areas of lowlands, high rolling mountains and hills, which therefore possess many species of plants and animals associated with those ecosystems.

\section{$<<$ Table 1. Land Status In Kelantan $>>$}

As required under the National Forestry Act 1984, the Forest Reserves (F.R) within the state covers 629,687 hectares, which are categorized into 12 classes (an additional class solely under State Park in Kelantan). As can be seen from Table 2, the total area for conservation in the State (No.2-7) covers an area of 78,682 hectares and together with the National Park (108,783 ha), these accounts for 187,465 or $12.55 \%$ of the land area in the state, which is well above the area required by IUCN which is $10 \%$ of the land area $(1,493,181 \mathrm{ha})$

\section{$<$ Table 2. Forest Classification In Kelantan>>}

The overall rapid development in the country and the awareness for the need to conserve forest areas for the environment, biodiversity, recreation etc. has prompted the idea for a state park in Kelantan. To strengthen the case for a state park in Kelantan a suitable area requiring some basic information had to be selected. A scientific expedition, with the participation of scientists from universities, research agencies, non-governmental organizations and government agencies, organized in central Mt.. Stong F.R in the western region of $\mathrm{g}$ from lowland forest to hill forest. The wide-ranging form of vegetation and wildlife as well as diverse physical features was favorable towards the establishment of a state park here. The findings were presented in a seminar on the 24-25 February 2004 attended by various agencies and state dignitaries. The seminar wholeheartedly endorsed that the central Mt. Stong F.R be turned into a forest park and the need for the Forestry Department to speedily submit the proposal to the State Government.

\section{Description of the project area}

Mt. Stong State Forest Park, which occupies the whole of central Mt. Stong F.R of 21,950 hectares in the mid western region of Kelantan (Figure 1), is under the administration of the West Kelantan District Forest Office. It is accessible from a number of routes i.e. from Jeli from the north and Gua Musang from the south. Presently the Stong Hill Resort is located at the entrance of the Park. The Stong Forest Park covers three different forms of forest ecosystem ranging from the hill dipterocarp forest to the upper hill dipterocarp forest and the montane forest. Mt. Stong is one of Kelantan's highest $(1,442 \mathrm{~m})$ mountains in the forest reserve. It is also part of the Stong Magmatite Complex forming the mountainous landscape. At each internal geological process of injections of magma granite, G. Stong is one of the only two locations in Malaysia. In addition, Mt. Stong features one of the highest waterfalls in Southeast Asia i.e. the Jelawang Falls where from a height of $590 \mathrm{~m}(1500 \mathrm{ft})$ the water falls onto a seven-tiered cascade. Other places of interests include the crystal clear water at the rapids of Lata Chenai and Jeram Renyok. Many new records of lower and higher plant and animal species were revealed in the 2003 Expedition and one new ginger species was discovered.

\section{$<<$ Figure 1. Location of Mt. Stong P.F.R $>>$}

\section{Capabilities and technological features of UPM-APSB's airborne hyperspectral imaging system kit}

UPM-APSB'S AISA is a state-of-the-art fixed-wing aircraft mounted commercial hyperspectral sensor developed and operated by Forest Geospatial Information \& Survey Lab (FGISL)/Aeroscan Precision (M) Sdn Bhd. (APSB) in Lebuh Silikon, Universiti Putra Malaysia. It is designed to provide near real-time, frequent, repetitive, accurate and reliable pushbroom instrument that acquire images in hundreds of registered, contiguous narrow spectral bandpasses such that for each element it is possible to derive a complete reflectance spectrum. The sensor is a complete system that consists of a compact hyperspectral sensor head, miniature GPS/INS sensor for precise positioning, data acquisition unit and special post-processing software (Figure 2). This small portable instrument, with a total weight of only $15 \mathrm{~kg}$ can be mounted on an aluminium metal plate that is compatible with a standard aerial camera mount, available in any fixed wing aircraft such as Cessna, Beechcraft, SkyVan and Nomad (Figure 3). Swath width is 360 pixels and field of view (FOV) in cross track direction $20^{\circ}$ which makes ground resolution from $1 \mathrm{~km}$ altitude approximately $1 \mathrm{~m}$ at a flight speed of $120 \mathrm{knots}(60 \mathrm{~m} / \mathrm{s})$. In addition, 20 pixels per swath for downwelling irradiance was acquired via a fiber optic irradiance sensor (FODIS). 
Accurate position information, necessary for image rectification is measured with Systron C-MIGITS II integrated GPS/INS unit, which includes 3-axial inertial measurement unit based on solid-state gyros, GPS receiver and real time Kalman filter. Figure 3 illustrated the complete configuration system for the sensor kit. The effect of the aircraft such as the lateral roll is monitored using data from an onboard gyroscope. The advantage of this sensor over other hyperspectral instruments is the flexibility in selecting the sensor's spatial and spectral resolution characteristics. Reflected light from the target below the aircraft is transmitted through a sensor lens and directed to a prism-grating-prism optical system, which splits the light into its component wavelength spectra. The refractive properties of the two opposing prisms allow for a linear projection of light onto the CCD array. The two dimensional array consists of a spatial axis of 364 detectors, and a spectral axis of 288 detectors. It is capable of collecting data within a spectral range of 430 to $1000 \mathrm{~nm}$ and up to 288 spectral channels within this range. Current operational collection configurations range from 20 to 70 spectral bands depending on the aircraft speed, altitude and mission goals.

The UPM-APSB's technology in question is based around an airborne digital push broom scanner operating in the visible/near-infrared range. UPM-APSB integrates the scanner (AISA) which uses on-board real time differential GPS for positioning and Precision INS for measuring and recording aircraft pitch, roll and yaw. This gives AeroMAP ${ }^{\mathrm{TM}}$ the ability to produce accurate base maps for State Forest Park development and management planning in Mt.. Stong.

\section{<<Figure 2: The UPM-APSB's AISA airborne hyperspectral imaging system kit >>}

\section{$<<$ Figure 3: A complete airborne hyperspectral sensor mounted on-board a RMAF C402B aircraft >>}

Resolution and accuracy of $0.5 \mathrm{~m}$ and above is achievable, and the base maps can be produced and draped over the digital terrain model. The advantages of airborne hyperspectral high resolution scanners and associated technology are flexibility and opportunistic deployment when ever required (i.e monitoring unpermitted logging) and measured information content more than a thousand times greater then satellite-based "observations". Most satellites have between three and five spectral bands; i.e, you can look at the forest in red, green or blue (RGB)-but the airborne kit has up to 288 spectral bands, so it is almost like flying a spectroradiometer in the sky. As such, the type of geospatial information which can be obtained from the images produced by this "bread-box" sized scanner, flown back and forth over areas of up to 600 ha; imaging 20 $\mathrm{km}$ strips of forested lands, can be characterized into two types: spectral and spatial information. The spectral information will allow for separation and identification of the differences in reflected radiation between surface objects. The spatial distribution of these objects and ground features allows for analyses in the spatial domain, such as identification of tree crowns of individual species, geological parent materials, etc.

UPM-APSB is looking forward to incorporate the airborne radar/ALSM/LIDAR, which is an imaging radar which should be able to fully penetrate forest canopies and achieve considerable ground penetration for biodiversity and geological measurement in deep mountain forests (Pope et al., 1994; Watt, 2005; and Wilson, 2005).

\section{Best management practices (BMP) of Mt Stong Forest for sustainable development of a state forest park}

The BMP of a mountain forest may be adopted from the elements and terms of reference in the Forest Management Plan (FMP) as outlined by Borhan and Dahlan (2006). Although, Mt. Stong State Forest Park is still in its infancy stage, the ultimate aim of the State Forest Department of Kelantan for the Forest Park is to be recognized as the best managed state forest park in the world. The Kelantan State Forestry Department vision recognizes the followings (Abdullah et al., 2006):

(a) The Park is the cornerstone to conserve nature at the state level and probably in the future, be integrated at the state level and probably later be integrated as part of a national forest park system under the National Forestry Act 1984.

(b) Th Park should ensure conservation of natural values for all time and for all peoples

(c) Continuing engagement between people and parks, including enhance opportunities for all to visit, participate in, learn, respect, enjoy and preserve the Park as a fundamental purpose of management, and

(d) The only use of the Park is nature-based and ecologically sustainable.

This vision can be made possible by establishing and managing with the involvement of interested stakeholders. Following this, a State Steering Committee for the Park headed by the Chief Minister will be established specifically to clearly state the vision, principles and aims for the Park future management. Subjected to a Five-Year Review, the Plan will be refined to ensure it remains a dynamic blueprint, responsive to emerging issues while providing a firm and clear overall direction, rolling into the future. Meanwhile, the Scientific Expedition in 2003 qualified Mt. Stong as a highly potential area for a state forest park due to certain qualities it possesses, which are as follows:

(a) Comprehensive meaning that the Park covers a significant range of samples of regional ecosystems of the Peninsular

(b) Adequate meaning that the Park is of a sufficient size to enable natural integrity, including the species diversity, of the park to be maintained; and 
(c) Representative meaning that the samples of regional ecosystems include the maximum possible diversity of their plant and animals communities.

The Expedition only covered 800 ha or 3\% of the Mt. Stong Park area and thus a large area still abound for further study. The rich natural assets of Mt. Stong Forest Park however need to be managed based on a world class system of management. In this respect, a long term Master Plan over a hundred years will be drawn up. This Master Plan will be reviewed every five years, with public participation to evaluate the progress towards the stated principles and aims, and to consider new issues and circumstances. In order to ensure the successful establishment of the Stong State Forest Park as the best managed park, three committees have been formed, namely, Steering, Management and Technical Committees. Kamaruzaman and Dahlan (2006) proposed that the management of the Park will be carried out by the Management Committee headed by the State Secretary, with the following roles:

(a) Prepare an integrated management plan encompassing all the resources available for the Park

(b) Review and reinforce the role of the Park through proper strategies and plans

(c) Identify where systems and management need to be improved, and

(d) Identify actions needed to achieve vision.

The daily administration and management of the Park will be carried out by the Technical Group headed by the State Forestry Department. At the two top-level committees formed, representatives from the political, state agencies, nongovernmental organizations as well as interested groups, are committee members

In order to ensure the BMP of Mt. Stong forest resources as a State Forest Park, Dahlan and Abdullah (2006) identified four Park Management Plan Principles which must be adhered to as follows:

\subsection{Protecting Stong Forest Park for Its natural heritage}

Mt. Stong State Forest Park provides scenic backdrops of the Jelawang Falls; the rolling hills and the granite outcrops as tourist attractions. For many people who live away from nature, it gives a rare chance to experience the beauty and the sometimes harsh reality of the natural world. By protecting the diversity of landscapes, it provides the opportunity for people to connect with the forest and to experience and understand our natural heritage. For some people, quiet times in the Park can be a spiritual experience. The scenic landscapes represent the living history of our relationships with the forest. They are unique, irreplaceable parts of our identity, and provide opportunities for enjoyment, relaxation, recreation and education.

Principles: The Stong Forest Park will be permanently protected under the National Forestry Act 1984 and its natural integrity will be conserved under sustainable forest management, with its natural values protected and presented.

\subsection{Working with local communities}

Stong Forest Park can generate substantial economic benefits for the local communities where they can be trained to become guides or operate food and supply stores for visitors. As well as the direct income from tourism which they can bring, the Stong forest Park can provide vital "ecosystem services" to the community. For example, protecting watersheds provides relatively reliable water for agricultural and urban lands, erosion, and common effects of widespread land clearing. The large uncleared tracts of natural vegetation absorb greenhouse gases.

Principle: The Stong Forest Park will be managed in the context of surrounding landscapes with participation and involvement of local community needs and aspirations.

\subsection{Sustaining recreational and tourism opportunities}

For many people, Stong Forest Park can be a popular place to visit on weekends and holidays - to camp, picnic, hike, climb, enjoy a change of scenery, view wildlife or have a good time outside with family or friends. While facilities for camping and picnicking were planned here, the emphasis is on low-key recreation in the natural environment, where people enjoy themselves in simple ways without lots of development or artificial activities.

Principles: Opportunities will be provided for people to visit, participate in, learn about, respect, enjoy, preserve and protect the Stong Forest Park's natural heritage. The Park will be managed to provide substantial and sustainable environmental, social and economic benefits to the local communities and the people of Kelantan while maintaining the intrinsic values of the Park. It will be managed to provide visitors with safe facilities and with information that will promote visitors awareness of the hazards present and the levels of skill and competence required to cope with the risks they may face.

\subsection{Enhancing State Forest Department management capabilities}

The previous three sections have dealt with particular aspects of protecting and presenting Stong Forest Park. The final section of the proposed Plan realizes that its human resources and the management can become progressively more skilful by raising the professionalism of the workforce, by better involving the skills, knowledge and industry and by using 
progressively better information bases. The management can be more effective by supporting the workforce with trust, encouragement and adequate resources, and by developing and implementing good partnerships, policies and planning systems. In addition, it can be adaptive by becoming an innovative organization which learns through experience and is willing to try new ideas to be at the forefront of park management. The management of the State Forest Department will be more efficient by careful use of resources, delegation of responsibility to local levels wherever possible, communicating well and sharing information both within the agency and with other organizations. The principles of park management within sustainable forest management must ensure to remain as core factors in all decisions and activities. Stong Forest Park requires decisions at many levels. Planning and policy developments are effective mechanisms to gather information, to identify and integrate management decisions, and to transparently document a firm course of action. A high level of cooperation with other government agencies, including local government, is essential in many aspects of park management and may be defined in relevant plans.

Principles: The Stong forest Park will be planned and managed skillfully, effectively, adaptively and efficiently to maintain park values. Good management decisions will be made based on high standards of information and wisdom and community involvement in decision making. A dedicated, skilled and motivated workforce will manage the Park, using clear policies, directions and standards. Continual improvement in park management will be fostered through evaluation, learning, and reliable and logical allocation of resources.

\section{UPM-APSB'S airborne system kit as a powerful tool for managing mountain forest resources}

The UPM-APSB's technology in question is based around an airborne digital push broom scanner operating in the visible/near-infrared range. UPM-APSB integrates the scanner (AISA) which uses on-board near real time differential GPS for positioning and Precision INS for measuring and recording aircraft pitch, roll and yaw. This gives AeroMAP ${ }^{\mathrm{TM}}$ the ability to produce accurate base maps for State Forest Park development and management planning in Mt. Stong.

\subsection{Current timber volumes per stratified hectare by crown diameter}

With UPM-APSB's AISA airborne VIS/NIR scanner data alone, it is not possible to determine timber volumes directly, which is what an imaging radar can do (Strahler and Jupp, 1990). With the UPM-APB's AISA-type instruments, however it is possible to do important measurements in this regard. Assessment of crown size and identification of most likely species are possible. If this data is combined with ground derived models that relate crown size to tree height and diameter or tree size (allometric relationships) for the various individual species in the area, it would be possible to derive the average tree size, height and hence standing timber volume per hectare (Table 3). Hopefully, with the imaging profiling radar to be incorporated, we can directly measure forest height as well as general (ground) topography in the area of interest. At very high spatial resolution of AeroMAP ${ }^{\mathrm{TM}}$ AISA sensor ( $1 \mathrm{~m}$ pixels), it would be possible to develop necessary software for use in counting the number of tree crowns and timber volume in a given area under study.

\section{$<<$ Table 3. Tree species counts and timber volume estimates in Mt. Stong P.F.R >>}

\subsection{Individual Species Identification and Mapping}

Species identification is only possible with the UPM-APSB's AISA if a spectral library for all the likely tree species in the area is available, and at the same time, if there are sufficient spectral differences among species for the differentiation process. With the UPM-APSB's AISA, we have an advantage over all other technologies for this to succeed since spectral library profiles of more than 100 dipterocarp and non-dipterocarp species have been developed (Figure 4). We can airborne at high enough resolution to obtain spectrally 'pure" pixels for the crowns of the species to be identified, and in addition, the UPM-APSB's AISA is a calibrated spectroradiometer with high enough signal-noise ratio to be able to detect very small differences between spectra, if there are any. Figure 5 shows the image species identification and classification map of Mt.Stong based on an individual Meranti Seraya spatial distribution for field tree marking purposes. Higher classification accuracies are possible, if the UPM-APSB data is combined with data from other instruments like multi-band radar or other ecological information such as topography, meteorology, soil, etc.

\section{$<<$ Figure 4. Some selected image spectral signature library of species in Mt.Stong $>>$ \\ $<<$ Figure 5. An individual Meranti Seraya distribution map for tree tagging purposes $>>$ \\ 6.3 Forest features of special interest}

The only quality parameters we can confidently measure in an undisturbed virgin mountain forest with the airborne sensor are turbidity and chlorophyll content. However, in this area, small streams and rivers are overshadowed by the dense forest canopies at most time. Pixel sizes in the UPM-APSB's AISA data need to be small enough (less than $1 \mathrm{~m}$ ) to be able for use in smaller forest streams that are visible from the air. However, most of the clear unpolluted rivers and other features of interests can be easily mapped and quantified from the image as shown in Figures $6 \mathrm{a}-6 \mathrm{~b}$ and $7 \mathrm{a}-7 \mathrm{~b}$.

\footnotetext{
$<<$ Figure 6a. The unpolluted clear flowing Rantai river distributaries mapped in Mt.Stong P.F.R $>>$

$<<$ Figure 6b. The beautiful Mt. Stong waterfall for swimming and picnic site $>>$
} 
$<<$ Figure 7a. Possible development of mountaineering and rock climbing activities in one of the steep rocky mountain Mt. Stong P.F.R $>>$

$<<$ Figure 7b. One of the magnificient limestone caves "Gua Bogo" suitable for scientific expedition and eco-tourist attraction $>>$

\subsection{Existing Logging Road/Skid Trails Impacts on Forest}

Due to the potential for mapping land-use/cover, bare soil and different vegetation types with UPM-APSB airborne sensor, it becomes more a GIS task to map the effects of different logging and forest road activities on the forest. UPM-APSB's airborne data can then discriminate (and hence map into a GIS) road/skid trails types, locations, widths, buffers, etc. The current existing forest roads/walking trails buffers in the area can be easily and precisely mapped and inputted into a GIS fomat as shown in Figure 8.

Retention of information to compare future measurements with present mapping (change detection) is possible. One of the key features of this system technology is that it is based on a calibrated instrument and includes algorithms for physically-based atmospheric correction. This result in images scaled in terms of 'true reflectance', which is really the only type of remotely airborne sensed data, which can truly be used for change and detection mapping of features suitable for a state forest park planning and development.

$<<$ Figure 8. The forest road buffers overlays with walking trails and rivers in the GIS format for potential state forest park sites in Mt. Stong P.F.R $>>$

\subsection{Timber salvage harvesting and utilization plans}

Since information on precision forestry can be obtained in near "real time", Timber Utilization Plans can be prepared on an annually basis. These specify the location of the proposed timber salvage harvesting and stand management operations (Figures 9a and 9b). Plans can be provided to key stakeholders for comment and should be available in Kelantan State Forest Department office and on the website. Opportunities will be provided for comment on proposals before plans are finalized. Future timber utilization will conform to the requirements of this Plan.

Coupe plans will be prepared for the timber salvage harvesting operation since matured big-sized timber trees such as Meranti Bukit can be easily located from the UPM-APSB airborne sensor (Figure 10). These specify the boundaries of the harvesting coupe, harvesting standards, habitat tree retention requirements and any other management requirements. Coupe plans should be supported by The Malaysian Timber Harvesting Procedures which detail environmental and operational requirements for commercial harvesting. They are binding for logging contractors and provide the basis for the application of The FAO Timber Harvesting Guidelines.

$<<$ Figure 9a. An individual species classification map of Meranti Seraya showing their precise location of "big-sized" trees greater than $103 \mathrm{~cm}$ DBH mapped in Mt. Stong F.R $>>$

$<<$ Figure 9b. An estimated 40 years-old Meranti Seraya discovered from UPM-APSB sensor $>>$

$<<$ Figure 10. The lower buttress portion of one of the biggest Meranti Bukit mapped in Mt. Stong F.R proposed for future timber salvage harvesting $>>$

\subsection{Forest management prescriptions and zoning}

Being most data on the Mt. Stong State Forest Park can be made available in near real time in a GIS format and image maps, the management prescriptions can provide detailed information and standards for the conduct of timber salvage harvesting and other State Park forest management operations. The Prescriptions and Zoning will be developed in consultation with experts in disciplines such as forestry, forest engineering, economy, botany, wildlife biology, ecology, watershed catchments management, water resources, cultural heritage and recreation/eco-tourism planning. It is expected that zoning such as Special Protection Zone, Special Management Zone and General Management Zone comprising of biodiversity conservation, water management, forest protection, forest production, recreation and eco-tourism, cultural heritage sites will be established and prescribed on the image maps.

\section{Conclusion}

The core of this paper is to provide useful information of airborne spectrometry using UPM=APSB hyperspectral imaging technologies to guide policy development in managing mountain forest in G. Stong F.R. The capability of AeroMAP ${ }^{\mathrm{TM}}$ to produce reliable and accurate resource measurements and maps indicated that it can provide a new force in the management and planning of tropical mountain forests, especially that of G. Stong as a Kelantan's unique state forest park. With the existing natural features of interest identified, quantified and mapped by the UPM-APSB airborne hyperspectral sensor, including the mapping of precise location of "big-sized" trees and their volume estimates, the mountain forest in Mt Stong is a magnet for outdoor recreation and forest eco-tourist enthusiasts, blessed with natural places of great beauty that can draw millions of local residents, domestic and foreign eco-tourists each year. If well planned and managed, G. Stong Sate Forest Park should be able to contribute to the allure of Kelantan, not only do this 
state forest park provides access to varied and often unique natural, historic and cultural experiences but it also protects, preserves and maintains a dwindling supply of natural resources for enjoyment today and preservation for our younger generation tomorrow.

It is highly recommended that G. Stong be managed into a state forest park and therefore requires a Comprehensive State Forest Park Master Plan blue print. This is to guide the development of a diverse, balanced, statewide forest eco-tourism and outdoor recreation system towards meeting current and future needs providing a comprehensive planning and implementation process. Therefore, a dynamic updated resource supply inventory geospatial database in GIS format is deemed necessary to provide the foundation for Mt. Stong's BMP implementation process. UPM-APSB airborne hyperspectral data which is a "ready-made" GIS, should be in a position to facilitate access to the required data, tools and support needed by the Kelantan State government especially her Forest Department to more effectively and efficiently perform tasks associated with Stong's mountain forest administration, natural communities, optimum boundaries and conceptual state forest park land use management zoning.

\section{Acknowledgements}

The authors would like to thank the Kelantan State Forestry Department, Kelantan state government and Aeroscan Precision (M) Sdn Bhd for the generous funding of this project especially in providing the field staff and aircraft, assisting in the digital image analysis and ground support team, respctively to make this project successful. The authors are also grateful to Y.Bhg. Dato' Hj. Dahlan Taha for providing useful information on the Kelantan's forest resources facts and figures and the principles governing the management of a mountain state forest park.

\section{References}

Abdullah Sani Shafie, Kamaruzaman Jusoff and Dahlan Taha. (2006). State Park Development and Management Planning Using Airborne Hyperspectral Imaging System and GIS in Gunung Stong State Forest Park, Kelantan. Procs. Seminar on the Stong State Forest Park Management Plan "Towards the Best Managed State Park". Kamaruzaman Jusoff \& Dahlan Taha (Eds). 20 March 2006. Jabatan Perhutanan Negeri Kelantan, Kota Bharu, Kelantan. Malaysia. Pp. 11-22.

Borhan Mohd and Dahlan Taha. (2006). Management Planning For Gunung Stong State Forest Park, Kelantan, Malaysia: Some Considerations. Procs. Seminar on the Stong State Forest Park Management Plan "Towards the Best Managed State Park". Kamaruzaman Jusoff \& Dahlan Taha (Eds). 20 March 2006. Jabatan Perhutanan Negeri Kelantan, Kota Bharu, Kelantan. Malaysia. Pp. 40-50.

Dahlan Taha and Abdullah Sani Shafie. (2006). Gunung Stong State Forest Park-Towards the Best Managed State Park. Procs. Seminar on the Stong State Forest Park Management Plan "Towards the Best Managed State Park". Kamaruzaman Jusoff and Dahlan Taha (Eds). 20 March 2006. Jabatan Perhutanan Negeri Kelantan, Kota Bharu, Kelantan. Malaysia. Pp. $1-10$.

Kamaruzaman Jusoff and Dahlan Taha. (2006). Pre-liminary Findings of Airborne Hyperspectral Imaging System For Gunung Stong State Forest Park Planning and Development. Dahlan and Abdullah, 2006. Procs. Seminar on the Stong State Forest Park Management Plan “Towards the Best Managed State Park”. Kamaruzaman Jusoff \& Dahlan Taha (Eds). 20 March 2006. Jabatan Perhutanan Negeri Kelantan, Kota Bharu, Kelantan. Malaysia. Pp. 23-29.

Pope, K.O, Ray-Benayas, J.M and Paris, J. (1994). Radar remote sensing of forest and wetland ecosystems in the Central American tropics. Remote Sensing of Environment, 48:205-219.

Strahler, A.H and Jupp, D.L.B. (1990) Modelling bi-directional reflectance of forests and woodland using Boolean models and geometric optics. Remote Sensing of Environment, 34:153-16

Watt, P. (2005). Segmentation of yield class. Abstract. Forest Safe/Forestsat. June 2005. Information sheet distributed at XXII IUFRO World Congress, 8-12 August 2005, Brisbane, Queensland, Australia.

Wilson, J. (2005). Production statistics from LIDAR and Aerial Data. Forest Safe/Forestsat. June 2005. Information sheet distributed at XXII IUFRO World Congress, 8-12 August 2005, Brisbane, Queensland, Australia.

Table 1. Land Status In Kelantan

\begin{tabular}{|l|l|l|l|}
\hline No. & Status & Acreage (ha) & Percentage (\%) \\
\hline 1. & Total land area & $1,493,181$ & - \\
\hline 2. & Permanent Forest Reserves & 629,687 & 43.2 \\
\hline 3. & Wildlife Reserve & 108,783 & 7.3 \\
\hline 4. & State land Forest & 155,801 & 10.4 \\
\hline 5. & Alienated land & 598,910 & 40.1 \\
\hline
\end{tabular}


Table 2. Forest Classification In Kelantan

\begin{tabular}{|l|l|l|}
\hline No. & Kelantan Forest Classes & Acreage (ha) \\
\hline 1 & Production Forest & 551,005 \\
\hline 2 & Water Catchments & 41,924 \\
\hline 3 & Virgin Jungle Reserves & 3,444 \\
\hline 4 & Recreation & 5,057 \\
\hline 5 & Education & 4,150 \\
\hline 6 & Research & 2,157 \\
\hline 7 & State Forest Park & 21,950 \\
\hline & TOTAL & $\mathbf{6 2 9 , 6 8 7}$ \\
\hline
\end{tabular}

Table 3. Tree species counts and timber volume estimates in Mt. Stong P.F.R

\begin{tabular}{|c|c|c|c|c|c|c|}
\hline No & $\begin{array}{ll}\text { Name } & \text { of } \\
\text { Species } & \end{array}$ & $\begin{array}{c}\text { DBH } \\
<55 \mathrm{~cm}\end{array}$ & $\begin{array}{l}55 \mathrm{~cm} \leq \mathrm{DBH} \leq 60 \\
\mathrm{~cm}\end{array}$ & $\begin{array}{l}\mathrm{DBH} \\
60 \mathrm{~cm}\end{array}$ & $>$ Total No. & $\mid \begin{array}{l}\text { Timber } \\
\text { volume, } \\
\mathrm{m}^{3}\end{array}$ \\
\hline 1 & pulai & 0 & 0 & 944 & 944 & 5,352 \\
\hline 2 & keruing & 3,068 & 0 & 0 & 3,068 & 7,793 \\
\hline 3 & jelutong & 0 & 0 & 3,530 & 3,530 & 12,813 \\
\hline 4 & mt nemesu & 3,205 & 0 & 0 & 3,205 & 9,935 \\
\hline 5 & mata ulat & 3,585 & 0 & 0 & 3,585 & 4,051 \\
\hline 6 & kayu arang & 2,726 & 2,725 & 0 & 5,451 & 3,598 \\
\hline 7 & kempas & 6,114 & 0 & 0 & 6,114 & 8,988 \\
\hline 8 & putat & 4,008 & 0 & 0 & 4,008 & 2,766 \\
\hline 9 & resak & 5,907 & 0 & 0 & 5,907 & 3,190 \\
\hline 10 & penarahan & 5,223 & 0 & 0 & 5,223 & 3,734 \\
\hline 11 & mempening & 5,263 & 0 & 479 & 5,742 & 5,317 \\
\hline 12 & mt tembaga & 2,259 & 0 & 2,260 & 4,519 & 12,988 \\
\hline 13 & mt seraya & 2,647 & 548 & 4,472 & 7,667 & 26,604 \\
\hline 14 & nyatoh & 5,671 & 1,134 & 1,418 & 8,223 & 11,101 \\
\hline 15 & mengkulang & 4,291 & 0 & 1,431 & 5,722 & 6,581 \\
\hline 16 & medang & 5,517 & 591 & 197 & 6,305 & 9,388 \\
\hline 17 & tempinis & 4,551 & 0 & 0 & 4,551 & 5,507 \\
\hline 18 & minyak berok & 11,159 & 1,395 & 0 & 12,554 & 34,899 \\
\hline 19 & rengas & 5,534 & 0 & 0 & 5,534 & 6,032 \\
\hline 20 & kelat & 3,172 & 378 & 680 & 4,230 & 5,795 \\
\hline 21 & merpauh & 1,338 & 1,783 & 3,121 & 6,242 & 33,687 \\
\hline 22 & damar hitam & 2,079 & 0 & 2,079 & 4,158 & 5,156 \\
\hline 23 & mersawa & 4,138 & 0 & 690 & 4,828 & 3,211 \\
\hline 24 & kedondong & 2,849 & 0 & 950 & 3,799 & 3,217 \\
\hline 25 & bintangor & 3,175 & 0 & 0 & 3,175 & 2,014 \\
\hline 26 & $\begin{array}{l}\text { kembang } \\
\text { semangkok }\end{array}$ & 2,752 & 1,376 & 0 & 4,128 & 21,012 \\
\hline 27 & durian & 2,821 & 1,410 & 0 & 4,231 & 3,342 \\
\hline 28 & mt paan & 1,758 & 1,759 & 0 & 3,517 & 4,080 \\
\hline 29 & membuluh & 2,926 & 0 & 0 & 2,926 & 2,458 \\
\hline TOTAL & & 107,738 & 13,099 & 22,251 & 143,087 & 264,609 \\
\hline
\end{tabular}




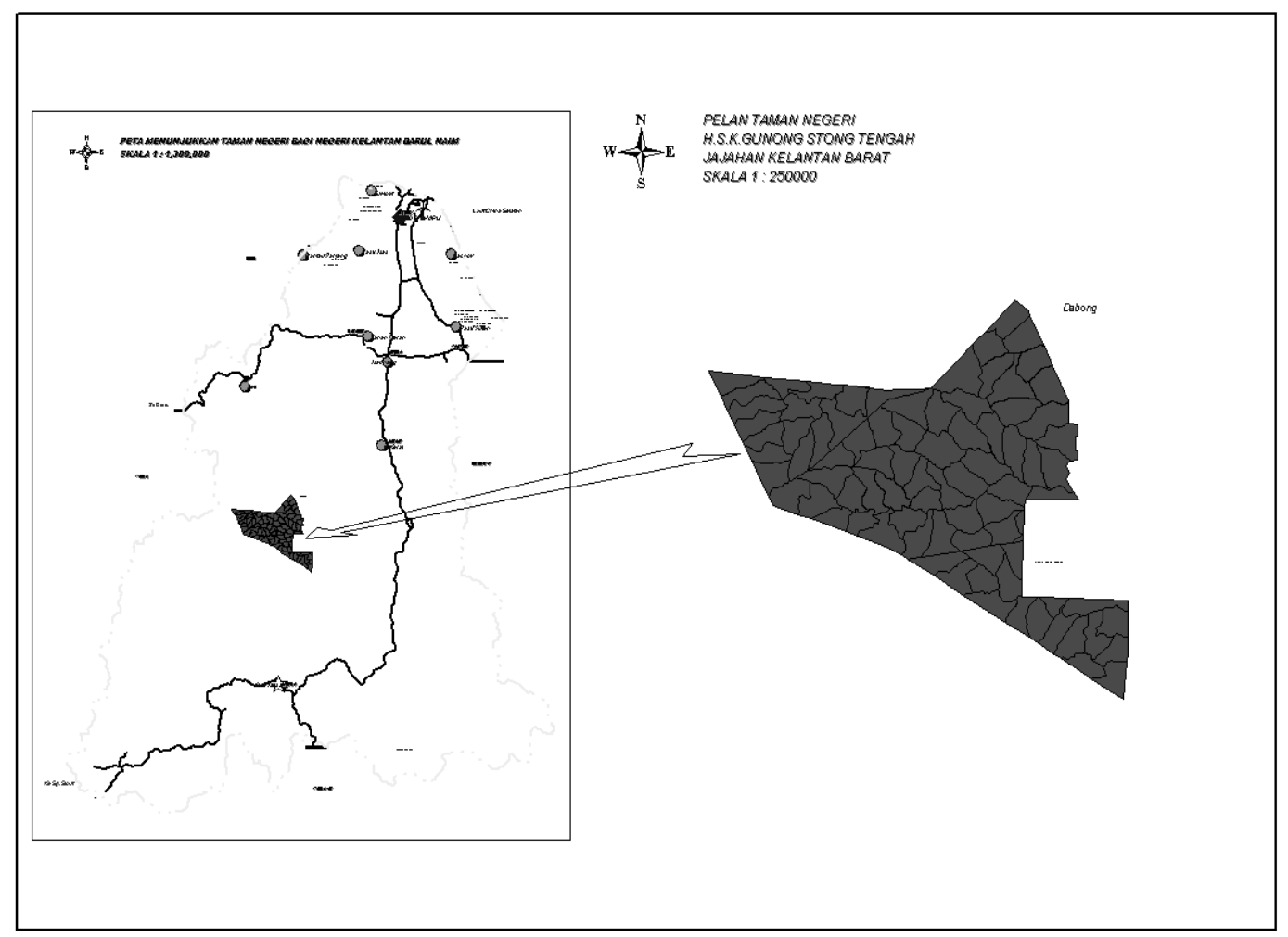

Figure 1. Location of Mt. Stong P.F.R

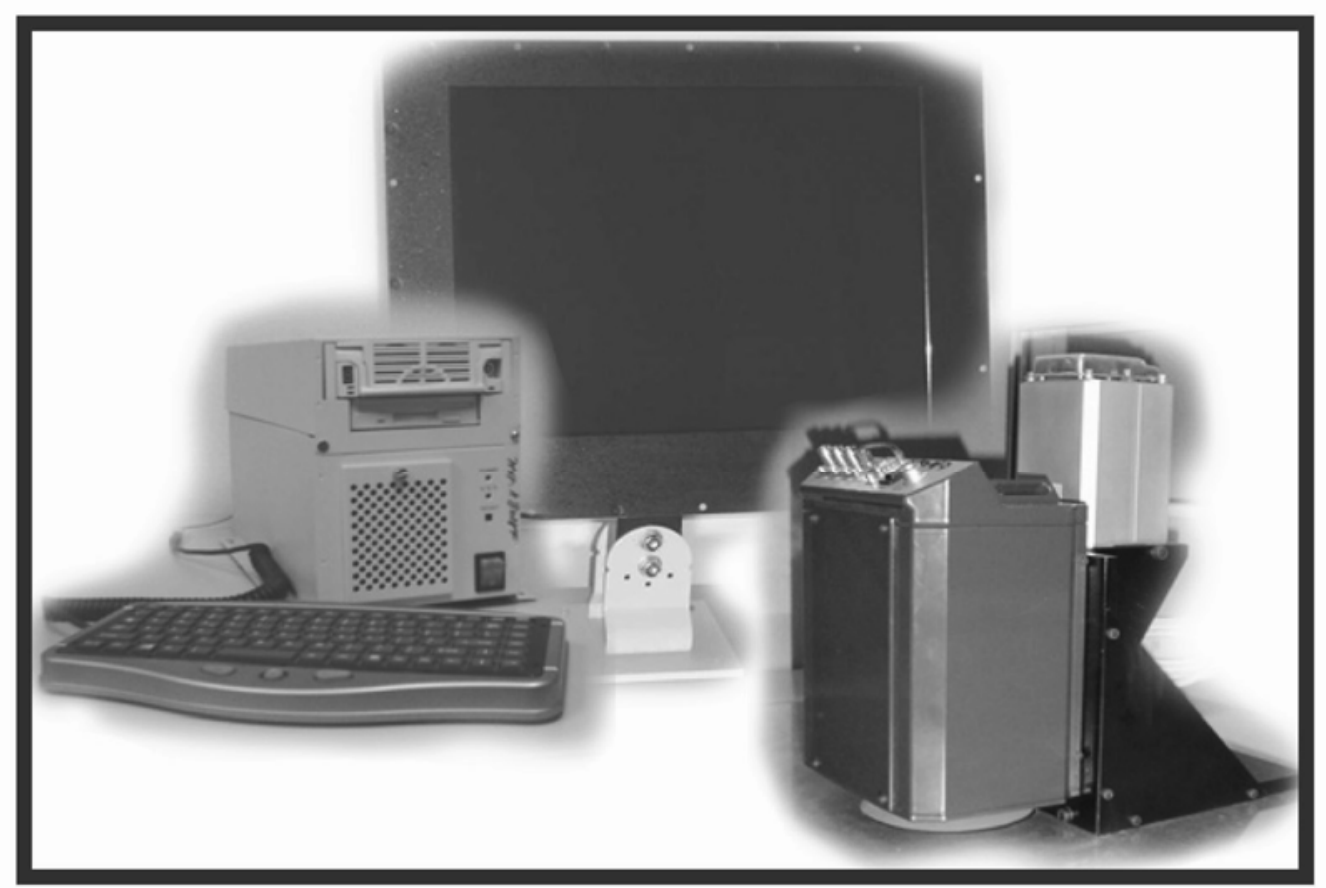

Figure 2. The UPM-APSB's AISA airborne hyperspectral imaging system kit 


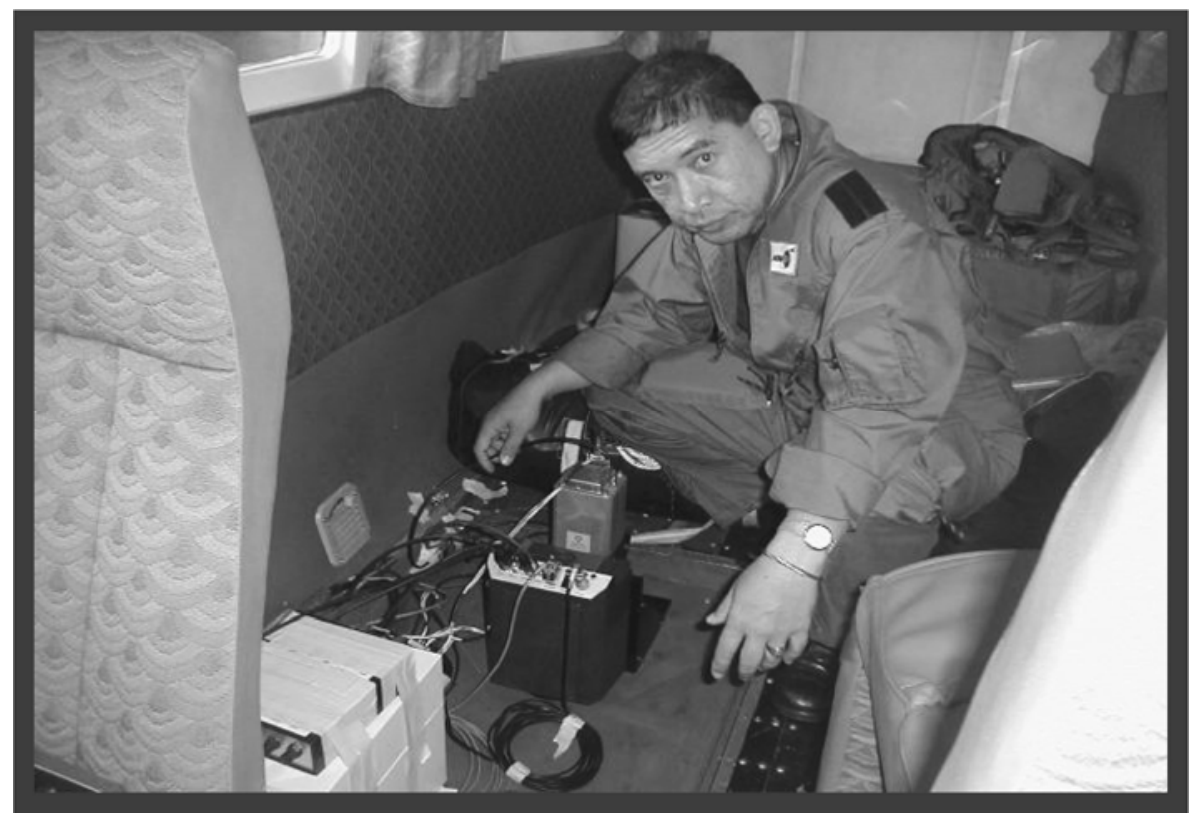

Figure 3. A complete airborne hyperspectral sensor mounted on-board a RMAF C402B aircraft

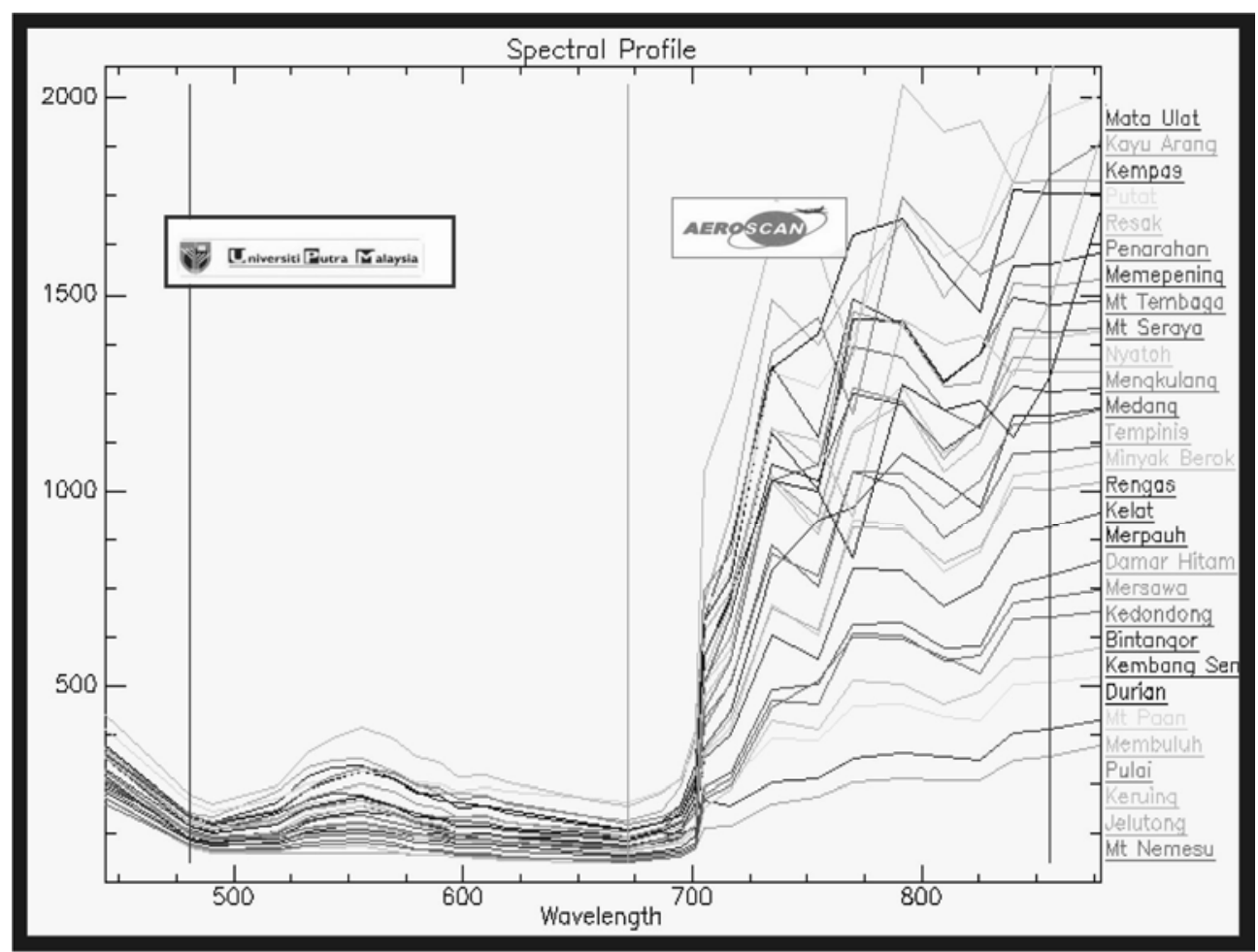

Figure 4. Some selected image spectral signature library of species in Mt.Stong 


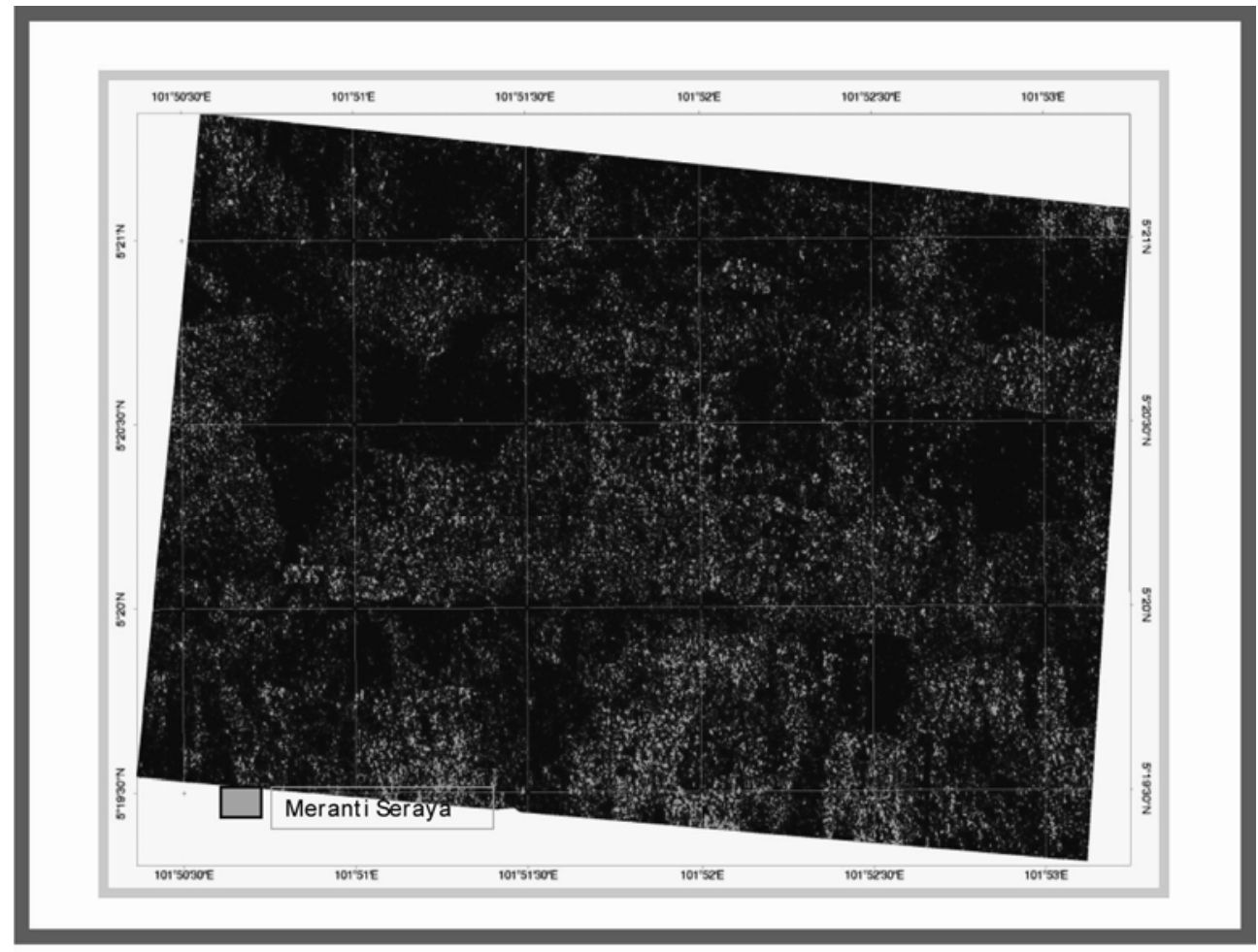

Figure 5. An individual Meranti Seraya distribution map for tree tagging purposes

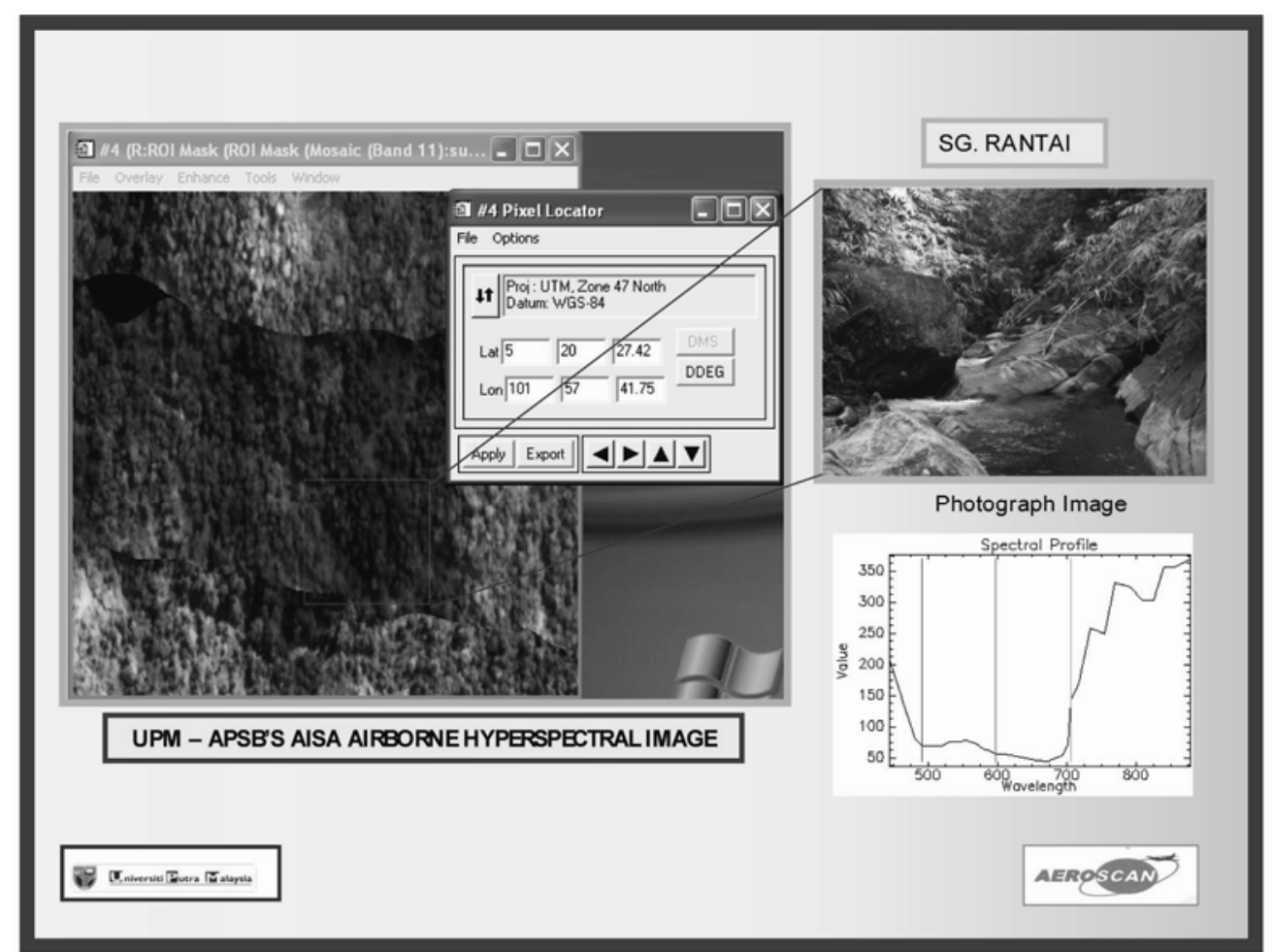

Figure 6a. The unpolluted clear flowing Rantai river distributaries mapped in Mt.Stong P.F.R 


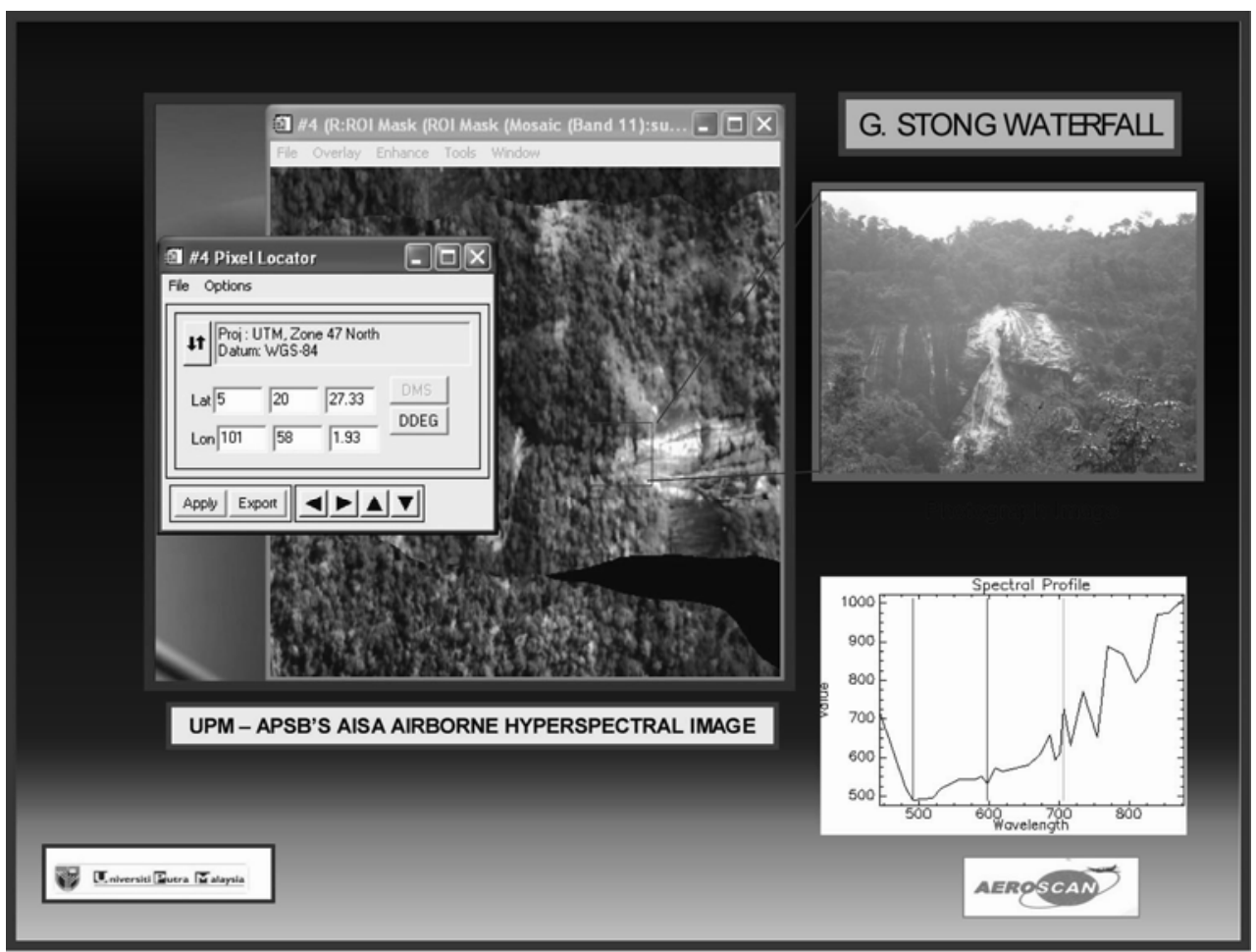

Figure $6 \mathrm{~b}$. The beautiful Mt. Stong waterfall for swimming and picnic site

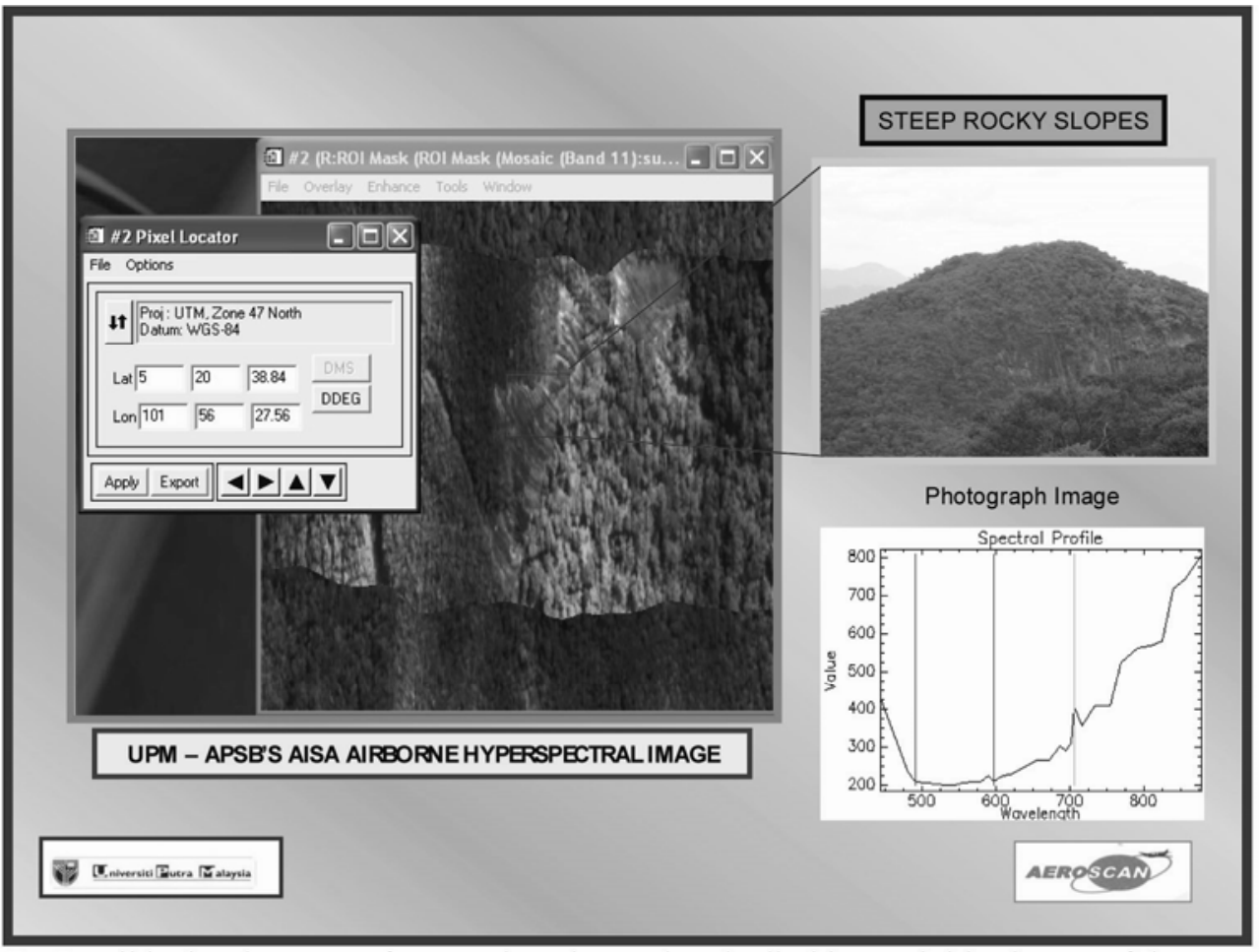

Figure 7a. Possible development of mountaineering and rock climbing activities in one of the steep rocky mountain Mt. Stong P.F.R 


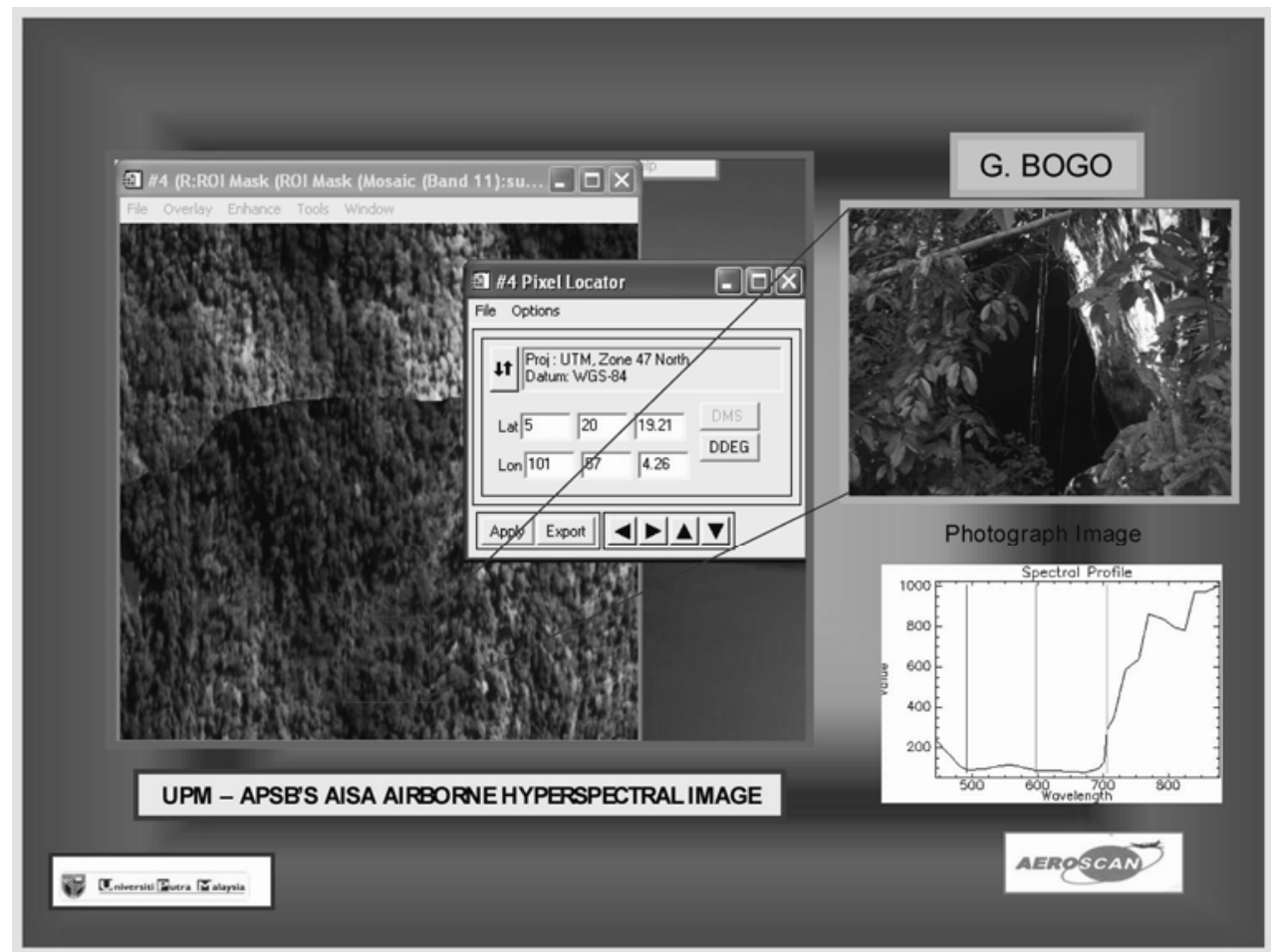

Figure 7b. One of the magnificient limestone caves "Gua Bogo" suitable for scientific expedition and eco-tourist attraction

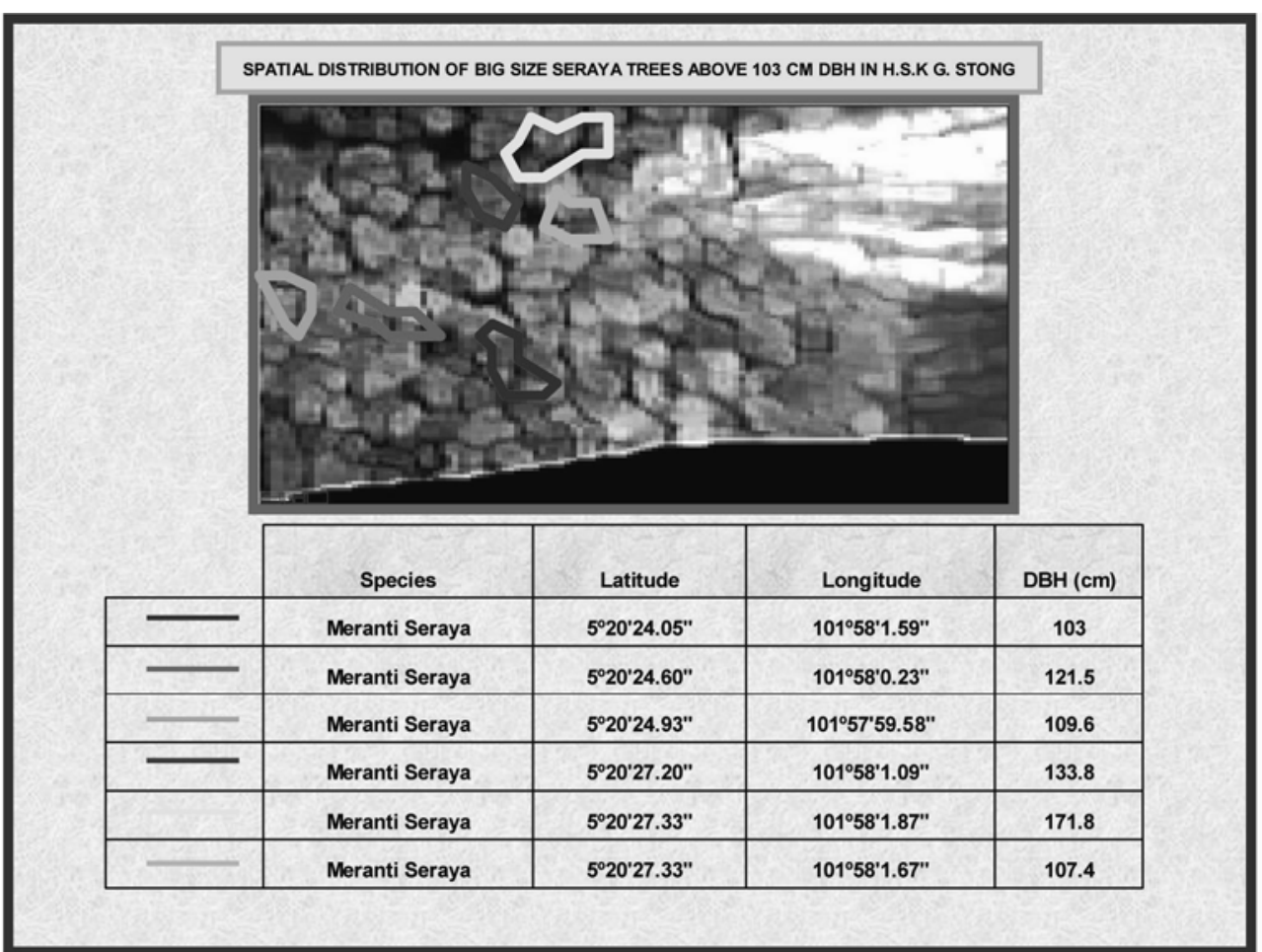

Figure 9a. An individual species classification map of Meranti Seraya showing their precise location of "big-sized" trees greater than $103 \mathrm{~cm}$ DBH mapped in Mt. Stong F.R 


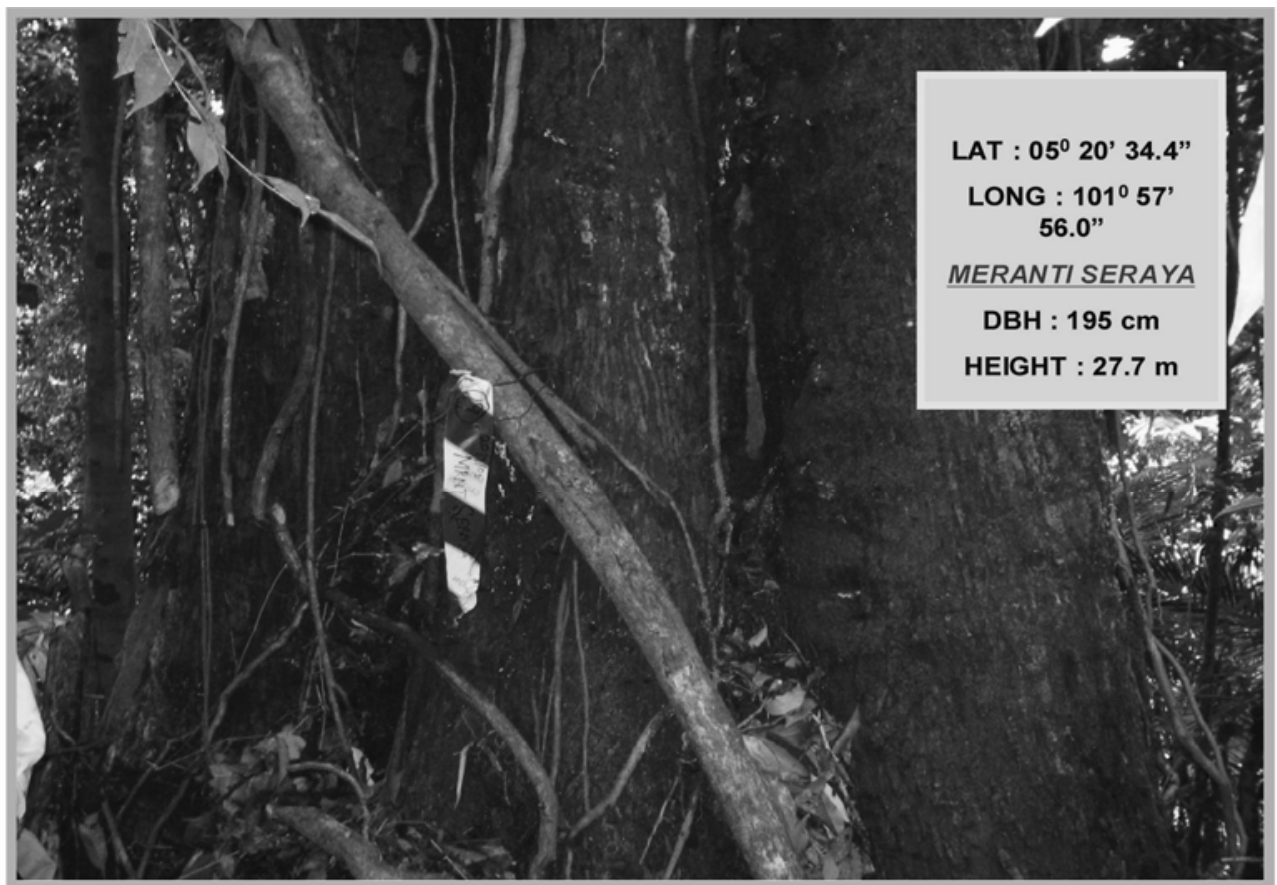

Figure 9b. An estimated 40 years-old Meranti Seraya discovered and mapped from UPM-APSB sensor

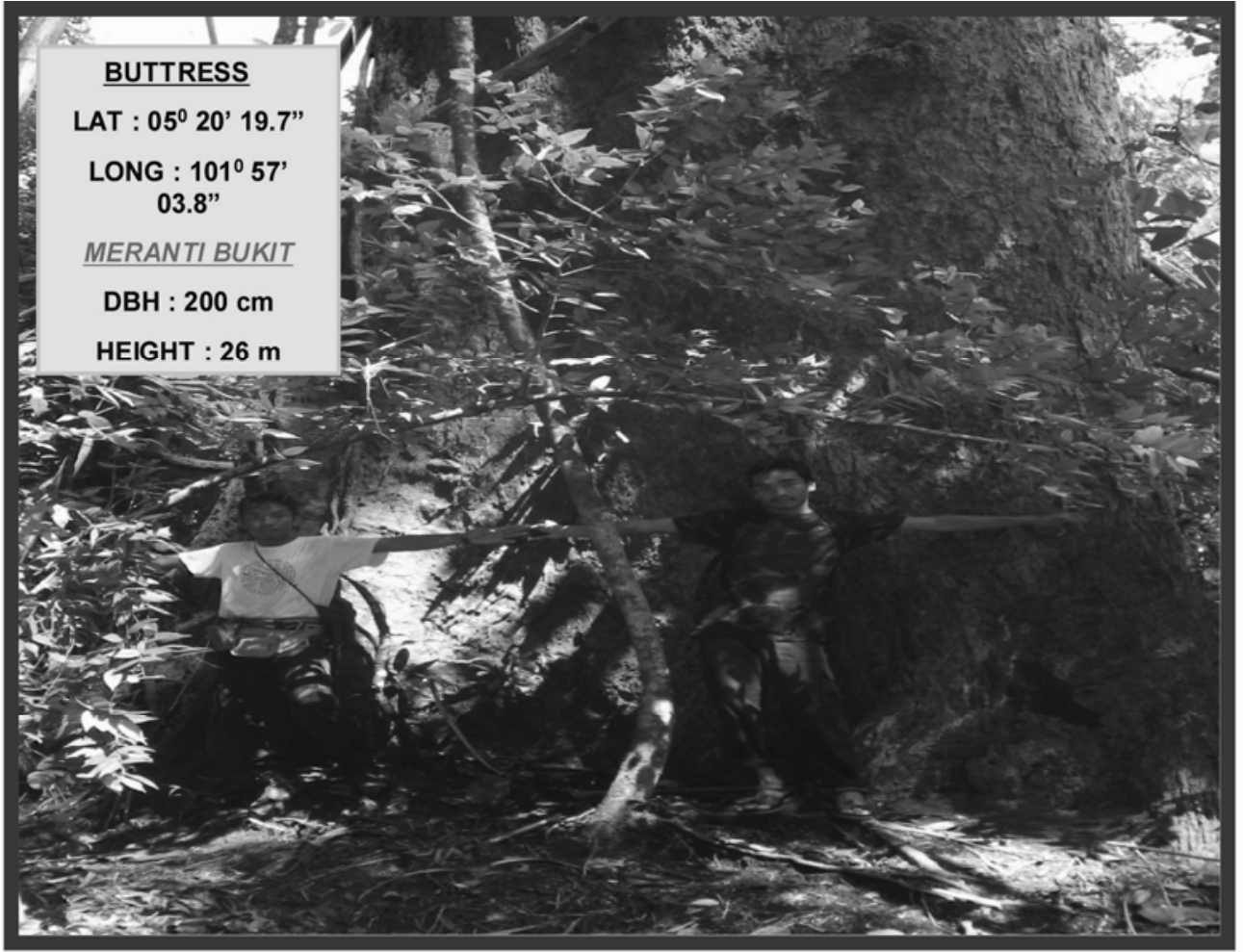

Figure 10. The lower buttress portion of one of the biggest Meranti Bukit mapped in Mt. Stong F.R proposed for future timber salvage harvesting 